\title{
腰椎レ線黒化度の年令的変化につけて
}

福岡県立柳川病院整形外科
田

\section{Age Differences in the Radiographic Density of Human Lumbar Vertebrae}

By

\section{S. Tanaka}

Orthopedic Clinic, Fukuoka Prefectural Yanagawa Hospital

\author{
H. Ikuta \& M. Kanazawa \\ Department of Orthopedic Surgery, Kurume \\ University School of Medicine
}

\begin{abstract}
Since vertebral osteoporosis is roentgenographically characterized by an increase in the bone permeability, the vertebral density of the different aged from the young up to the old was observed using roentgenographic measurements and some informations were obtained about its age differences.

The subjects examined were 156 cases ( $\hat{o} 73$, o 83 ) with low back pain without any evidence of tuberculosis and tumors, from age 13 to 79 , who had recently visited our clinic. In addition, out of them 16 cases of compression fracture were also investigated.

In both sexes, the vertebral density increares with the age, and it is characteristic that the female shows a comparatively high density from the forties. This period of age corresponds to menopause and it seems to be attributable to the fall of anabolic hormon.

The cases with the compression fracture are most common in the fifties and sixties, and next in seventies. As regards to the relationship between the vertebral density and fracture, it is demonstrated that the higher the vertebral density is, the more often the fracture occurs.
\end{abstract}

脊椎骨粗嫩症は, 変形性脊椎症と共に最も広く見ら れる老人性突患で, 老人人口の増加と共に重要な課題 になつて来ている。

私共の外来は, 筑後の農村地帯を背景にしている関 係加ら, 考人の腰痛症が非常に多く, 脊椎骨粗鬆症 の占める比重も従来考えていたより更に大きいことに 気付いた。

本症がレ線学的に骨の透過性の増大を特徵とする処 から，私共は未だ報告例がない様に思われる若年から 老年迄の腰椎レ線黒化度を, レントゲン学的計測に依 り追求し，その遂路的変化について若干の知見を得た ので報告する.

\section{調查对象および方法}

調査対象は，最近外来を訪れた腰痛を主訴とした患 者の中, 結核及び腫瘍を除外した 13 才 79才迄の 156 例（今 73, ㅇ 83 例）でての中, 16 例の陳旧性圧迫骨 折例に就いても検討した.

撮影条件は比較撮影という点からして, 常に同一濃 度を有するX楾写真と科学的根拠に基く撮影法が当然 要求されるので, 戦後紹介され最も代表的と思われる 米国式厚測撮影法（ミラー氏）に依つて調查した.

即ち, 表 1 の如く，撮影せんとする部位をZ Zirkel で 計測し，(厚さ) $\times 2+\alpha={ }_{K} V_{P}$ として之を各厚さの場 
表 1 撮 影 条 件

管 電 圧

厚さ $(\mathrm{cm}) \quad \begin{array}{llllllllllll}13 & 14 & 15 & 16 & 17 & 18 & 19 & 20 & 21 & 22 & 23\end{array}$

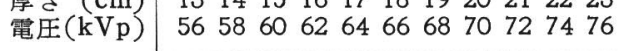

但し 厚さは脏部で測定 Bucky Blende 使用 $100 \mathrm{mAs}$

F. F. D. $\quad 100 \mathrm{~cm}$

増感紙極光 FS

フィルム さくら New Y-type

現像パコロール 自動現像機

装 㯰 島津桂号 $500 \mathrm{~mA}$ 型

黒化度計 Fuji Densito V

合に適応させた，尚，前提条件を正確にするため肥満 型および夫れに属すると思われる症例は全て除外し た. 計測部位は第 3 腰椎々体下外側縁である. その他 の条件は，表 1 亿示す如くである.

ここで，この厚測撮影法とは別個に Penetrometer （1〜20 mm のアルミ階段抜）の透過性と，腰椎の夫 れとを比較観察した.これは Penetrometer 単独に使 用するより真に近い濃度が得られる様に水ファントー ムとして使用した. 89 例（令 39 , 50 例）について である。

\section{調 查 成 績}

表 2 は男女年令階級別黒化度の平均值である. 即 ち, 各年令層に就いてみると男女とも遂齢的に黒化度 屯高い数值を示す様になり，乙とに女性に於いては男 性の夫れより高い数值を示す.

個々の症例を女性に就いて示すと次の如くである. 即ち, 図 1 は 22 才, 腰部捻挫の患者で黒化度 0.67 , Penetrometer $7.0 \mathrm{~mm}$ の吸収率に相当する.

図 2 は 57 才, deformans はほとんどなく, 黒化度 1.02, Penetrometer $1.0 \mathrm{~mm}$ で porose が著明であ る.

図 3 は 78 才, 黒化度 0.92 Penetrometer $1.0 \mathrm{~mm}$

\begin{tabular}{|c|c|c|}
\hline \multirow{2}{*}{ 年令 } & $\hat{\delta}$ & 우 \\
\hline & $\mathrm{M} \pm \sigma$ & $M \pm \sigma$ \\
\hline $\begin{array}{l}10 \sim 19 \\
20 \sim 29 \\
30 \sim 39 \\
40 \sim 49 \\
50 \sim 59 \\
60 \sim 69 \\
70 \sim\end{array}$ & $\begin{array}{l}0.62 \pm 0.06 \\
0.62 \pm 0.09 \\
0.65 \pm 0.13 \\
0.79 \pm 0.13 \\
0.88 \pm 0.17 \\
0.88 \pm 0.08 \\
1.00 \pm 0.12\end{array}$ & $\begin{array}{l}0.53 \pm 0.01 \\
0.71 \pm 0.08 \\
0.67 \pm 0.15 \\
0.88 \pm 0.12 \\
1.11 \pm 0.15 \\
1.02 \pm 0.17 \\
1.14 \pm 0.13\end{array}$ \\
\hline
\end{tabular}

で, この様に deformans と osteoporose はある程度 迄共存する症例がほとんどである.

男性では老年に於いても女性における如く骨の透過

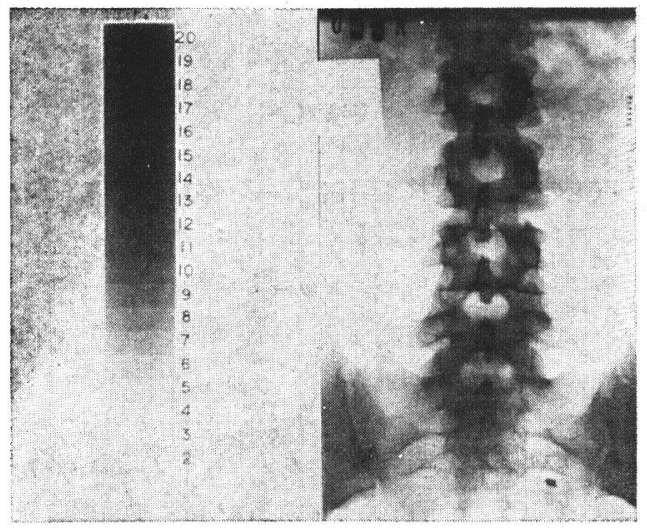

図 1

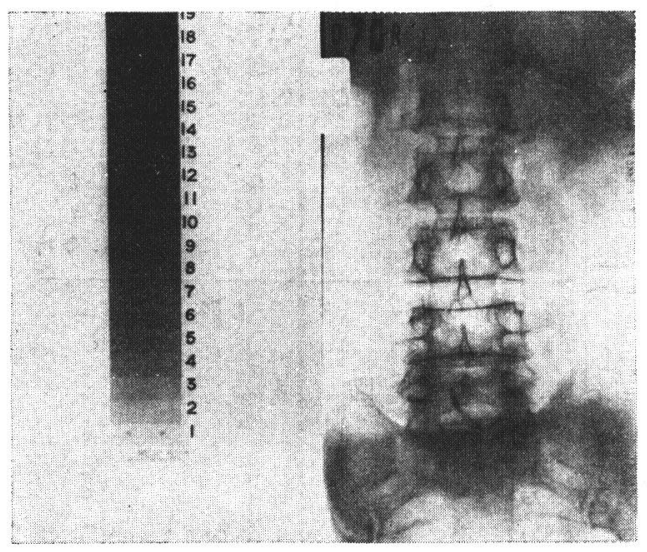

図 2

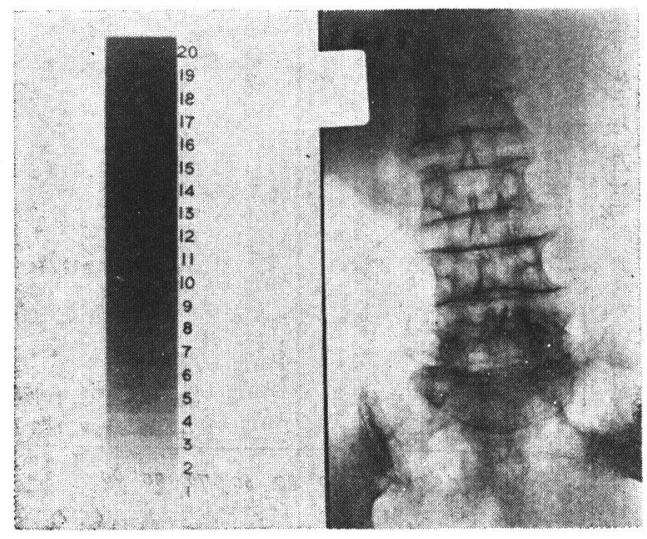

図 3 
性が著しく増強したと思われる症例には余り遭遇しな かつた.

ここで，女性偝常に 特異的なととは 40 才代から 比較的高い黒化度を示すことである. 即ち, 表 2 亿示 す如く 30 才代までは大した変化は認められないが, 40 才代加ら黒化度の平均值が 0.88 の示す如く急に増 加して来る.

以上の成績の推移を具体的に観察するために相関図 表であらわすと図 4 の如くである.

年令的に黒化度の増加するととに対し, 統計的に検

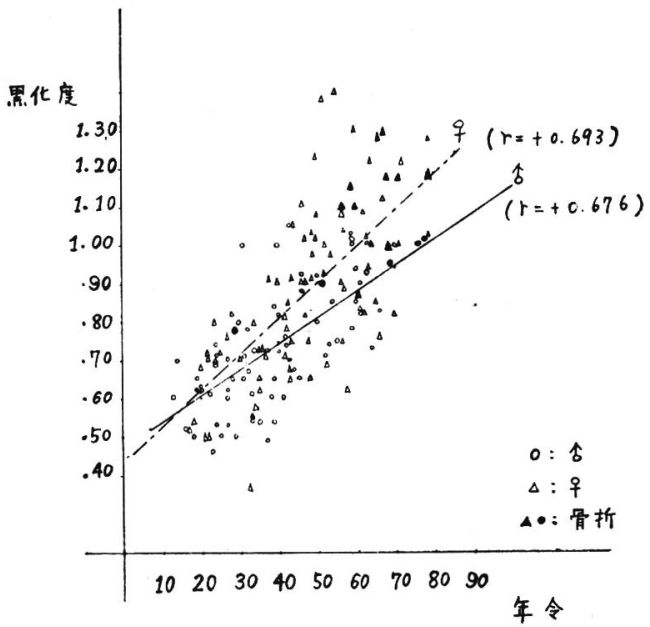

図 4

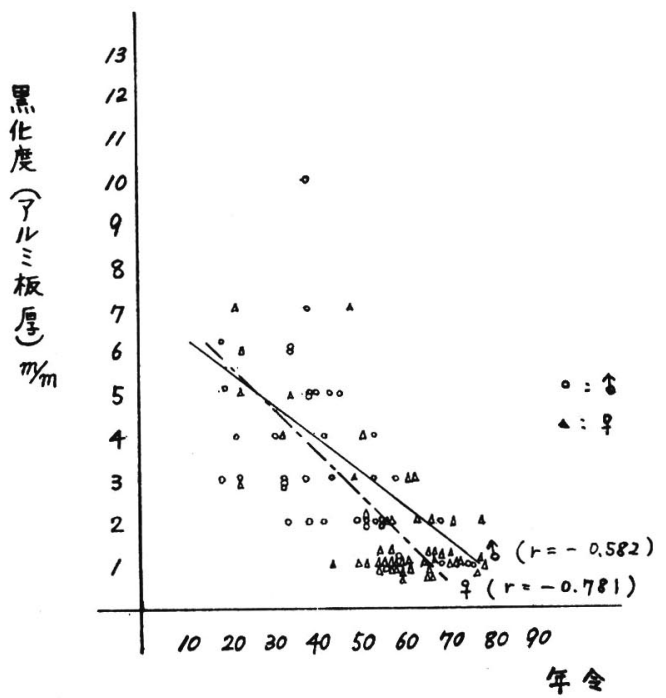

図 5
討した処 $1 \%$ の危険率で有意な值を示した.

図 5 はアルミ板 $\mathrm{mm}$ 厚に対する吸収率之年令之の 相関図表であるが, 年令と共にアルミ板厚あ小さい数 值を示す様になり，これも $1 \%$ の危険率で有意の差を 認めた。

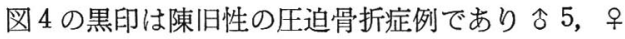
11 例である.

図 6 は受傷後 2 力月して来た 59 才 早 の圧迫骨折症 例で黒化度 1.15 , Penetrometer $1.0 \mathrm{~mm}$ である.

骨折例は図 7 の如く 50,60 年代保最多く, 70 才以 上がこれに次いでいる。黒化度と骨折との関係は, 図

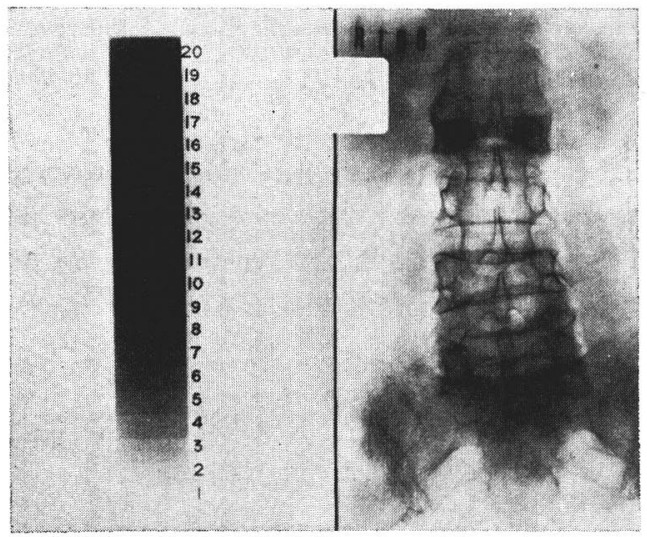

図 6

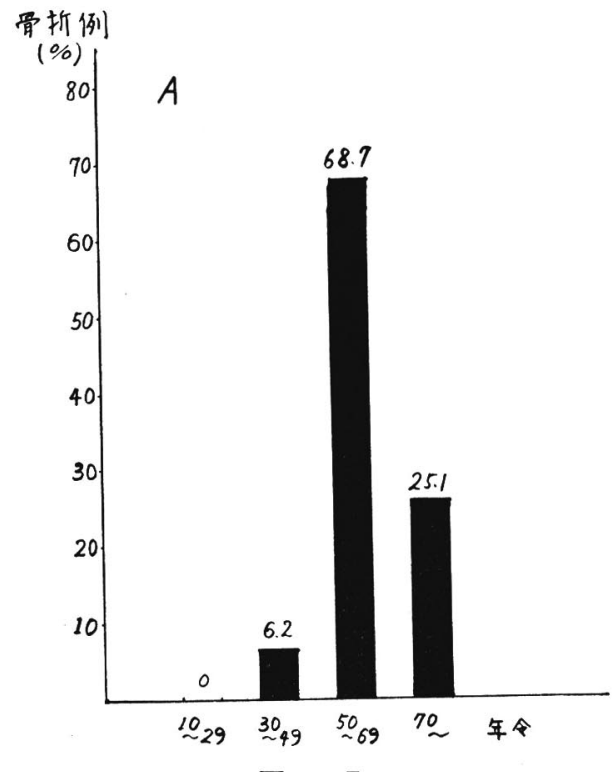

図 7 


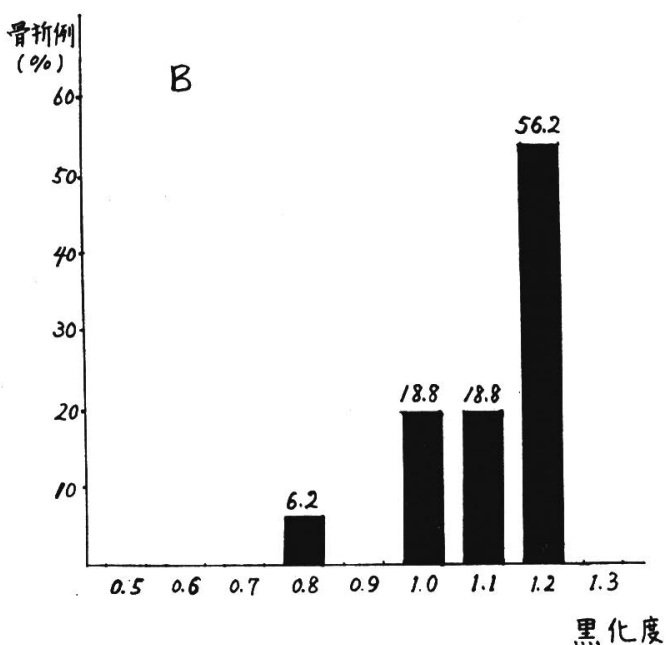

図 8

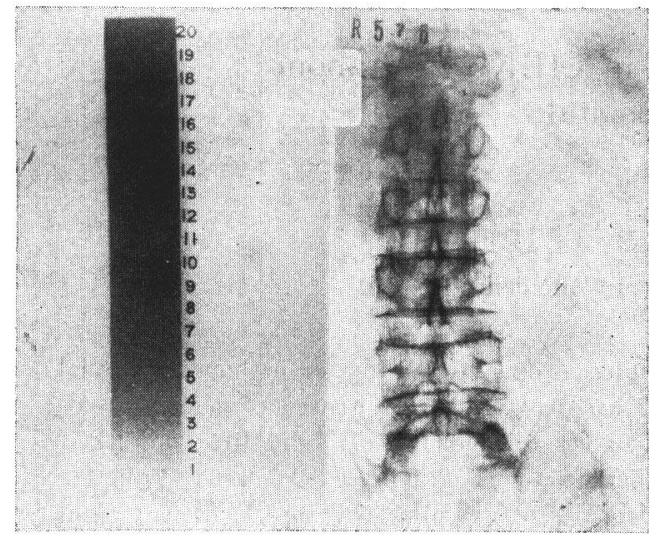

図 9

8 亿示す如く黒化度の数值の高い程骨折を起したすの が多く認められた.

図 9 は, 76 才今, 第 12 胸椎圧迫骨折例で, 黒化度 1. 0, Penetrometer $1.0 \mathrm{~mm}$ に相当する. 圧迫骨折例 は, この症例の如く胸腰推移行部に発生せるものが 16 例中 10 例 $(63 \%)$ で最む多かつた。，又，本症例は， 図 2 の症例之同様, レ線上 deformans は殆んど認め られない. Kivilaakso は deformans の見られない脊 柱は porose を起す伦険があると述べているが，この 症例は，夫れに相当する様に思われる。

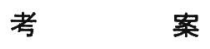

女性に於ける腰椎レ線黒化度の平均值は，30才代迄
は余り変化がないが，40年代から急に増加することは 先に示した. 我々がこの成績に非常に興味を持つた のは実にこの点であつて，乙の年代では Albright, Jasani 等の指摘する如く, 女性では Menopause で あり, anabolic hormon の脱落する時期と一致する からである. 又は遂年的に女性では男性より高い黒化 度值を示すが, 之は, 女性が男性に較べ, 非活動的で 廃用性萎縮に陥り易い上云うより，上に述べた如く， 女子では早期に而も完全に anabolic hormon の脱落 が起ると云うことに起因しているのではないかと考え る.

骨折例は, 50 60 年代に多く, 70 才以上がこれに次 いでいるが, 之は50〜60才代の方が活動的であり, 受 傷の機会む多く,70才以上では活動性も弱まり, 荷重 や運動を受け難い為と考えられる。

之等の圧迫骨折症例は洗面器を片手で担えたり，蒲 団等を中腰の姿勢で持ち上げたり日常生活中の極めて 些細な事にその誘因を求め得るものが多い.

斯の如く, 黒化度の大なものは, 骨皮質が菲薄であ り, 骨梁が粗となつている関係, 極めて軽微な外傷機 転によつてあ容易に圧迫骨折を招来し得るわけであ る.

臨床上, 骨粗影症は $X$ 線学的に骨の透過性即ち, 黒 化度の観察を主眼点とすることは勿論であるが，その 他各種の病的所見の診断上極めて 有意義であり，適 時, 計测を行い, その病態決定の指標となり得ると考 える。

我々は, その第一段階として, 腰椎レ線黒化度の年 令的差異に就いての評価を試みたが, 向後, 更に他の 骨格にあ調査例数を増して研究をすすめたい.

$$
\text { 結語 }
$$

以上, 圧迫骨折症例を含め腰椎レ線像における骨陰 影の透過性の差異と年令について報告した。

（稿を終るに臨み, 御校閲を睗つた恩師宮城教授並 びにレントゲン写真撮影に終始御協力を載いた福岡 県立柳川病院古賀尚充氏に深甚の謝意を表する.）

文献

1) Albright, F. \& Reifenstein, E. C., : The Metabolic Effects of Steroid Hormones in Osteoporosis. J. Clin. Invest., $26: 24,1947$. 
2)広谷速人 - 他: 脊椎骨粗䯿症の臨床的観察. 日 整会誌, $33: 19,1962$.

3) Jasani, C., Nordin, B. E. C., Smith, D. A. and Swanson, I. ; Spinal Osteoporosis and the Menopause. Proc. Roy. Soc. Med. 58 : 441, 1965.

4) Kivilaakso, R. : Fractures of the Osteoporo- tic Spinal Column. Ann. Chir. et Gynae. Fenn. 45 : Suppl. 8, 1956.

5）立松昌隆：骨粗鬆症。日整会誌，38:5, 1964.

6）若松英吉：骨粗鬆症の臨床と病理. 整形外科, $10: 643,1959$.

7) 横井勝朗 - 他 : 人体 $X$ 線撮影法. 上巻, 骨系統, 南江堂, 昭39.

\title{
当院脊損患者の臨床観察 特に尿路障害について
}

$\begin{array}{cccc}\text { 筑豊労災病院 } & \text { 整形外科 } & \\ \text { 大 } & \text { 屋 } & \text { 国 } & \text { 益 } \\ \text { 本 } & \text { 田 } & & \text { 保 }\end{array}$

九州大学整形外科（主任：天児民和教授）

星野鉄 士

\section{Paraplegia and Tetraplegia in CHIKUHO Labour Accident Hospital}

By

\author{
K. Ohya, T. Honda \& T. Hoshino \\ Orthopedic Clinic, Chikuho Labour Accident Hospital
}

There are 25 patients with paraplegia or tetraplegia due to trauma or orthopedic spinal diseases in CHIKUHO Labour Accident Hospital. 22 cases of them are in need of medical treatment or care, because of their paralysis or disturbance of activity of daily life. For their health control blood, urine (sediment and urinary bacterial test are involved), renal function and radiological views are regulary examined. The results of examinations for the recent eight months are summarized as follows :

1. Many cases show hypochromic anemia (Hemoglobin under $90 \%$ or hematocrit under 45 $\%$ are found in $72 \%$, respectively).

2. Usually, urine are acid, and leucocytes, opacity or epithelial cells are found in over $70 \%$.

3. Positive Urocheck test are obtained in $77 \%$ and positive bacterial culture are succeed in $61 \%$. In $80 \%$, both agree in views.

4. Although $72 \%$ show under 1.018 of the maximum spcific gravity in the thirst test or hyposthenuria, the results of phenolsulfonphthalein test are almost normal.

5. Regions of bony lesions have usually healed by osseous intention, but one case shows complete ankylosing spondilitis.

Cystograms are revealed: the reflux in three of 16 cases (two are unilateral and one is bilateral), Schramm's phenomen in 11 of 16 cases and the beam-formation or diverticulum in 10 of 16 cases.

In the intervenous pyelogram, caliectasis and ureteral dilatation are impotant.

Paranephritic abscess and intermittent hydronephrosis with floating kidney have need of urologist's advice. 